\title{
PENGARUH DEBT TO EQUITY RATIO (DER), RETURN ON ASSET \\ (ROA) DAN EARNING PER SHARE (EPS) TERHADAP PRICE TO BOOK VALUE (PBV) PADA PERUSAHAAN TELEKOMUNIKASI YANG TERDAFTAR DI BURSA EFEK INDONESIA PERIODE 2009-2013
}

\author{
Maman Suryaman \\ Mamansuryaman007@gmail.com \\ Universitas Ahmad Dahlan \\ Rikha Muftia Khoirunnisa \\ Move.tya@gmail.com \\ Universitas Ahmad Dahlan
}

\begin{abstract}
ABSTRAK
This study aims to analyze the effect of Debt to Equity Ratio (DER), Return On Assets (ROA), and Earning Per Share (EPS) on Price to Book Value (PBV). The sample used was a telecommunications company listed on the Indonesia Stock Exchange in the 2009-2013 period, in which there were six companies. The statistical method used is a multiple linear regression model. From the results of the Classical Assumptions test that is a test for normality, autocorrelation, multicollinearity, and heterosecdasticity, followed by multiple linear regression testing. The results showed that simultaneously (simultaneously) the variable Debt to Equity Ratio (DER), Return On Assets (ROA), and Earning Per Share (EPS) significantly influence the Price to Book Value (PBV) with a significance of 0,000. While partially only Debt to Equity Ratio (DER) with a significance of 0,000, Return On Assets (ROA) with a significance of 0,000 that significantly influence the Price to Book Value (PBV). While Earning Press hare has no significant effect on Price to Book Value (PBV) with a significance level of 0.273 .
\end{abstract}

Keyword: Debt to Equity Ratio (DER), Earning Pers hare (EPS), Return On Asset (ROA) and Price to Book Value (PBV)

\begin{tabular}{l}
\hline \multicolumn{3}{c}{ PENDAHULUAN } \\
\cline { 2 - 2 } Dunia bisnis sekarang ini \\
mengalami perkembangan yang sangat \\
pesat. Perkembangan tersebut dapat dilihat \\
dari banyaknya perusahaan-perusahaan \\
baru yang bermunculan dengan \\
keunggulan masing-masing yang \\
menimbulkan persaingan bisnis menjadi \\
semakin ketat. Hal ini juga terjadi pada \\
industri telekomunikasi di Indonesia. \\
Telekomunikasi seluler saat ini sudah \\
menjadi suatu kebutuhan yang utama bagi \\
masyarakat, khususnya telekomunikasi \\
seluler berbasis Global System for Mobile \\
(GSM) yang sudah akrab di telinga \\
masyarakat Indonesia. Pengguna GSM \\
sendiri tidak terbatas hanya pada kota-kota
\end{tabular}

besar tetapi sudah mencapai pelosokpelosok daerah di seluruh Indonesia. GSM sendiri masuk di Indonesia pada tahun 1990-an namun baru pada akhir tahun 1993 PT. Telkom memulai proyek GSM tersebut hanya pada cakupan Pulau Batam dan Bintan. Setelah itu mulai muncul beberapa pemain dalam industri berbasis GSM tersebut, diantaranya PT. Satelit Palapa Indonesia (Satelindo) yang berdiri pada tahun 1994 dan PT. Excelcomindo Pratama yang berdiri pada tahun 1996, dimana ketiga perusahaan tersebut adalah cikal bakal suksesnya perkembangan GSM di Indonesia.

Dalam mengembangkan usahanya, perusahaan memerlukan tambahan modal yang didapatkan melalui berbagai cara, 
salah satunya dengan memutuskan untuk go public. Tentu saja tidak mudah bagi emiten untuk menarik investor agar bersedia menanamkan modalnya, karena masing-masing investor memiliki kriteria yang berbeda dalam menilai suatu investasi. Pada dasarnya harga saham merupakan acuan para investor dalam mengambil keputusan investasi. Harga saham sering kali berubah-ubah menyesuaikan dengan tingkat penawaran serta permintaan.

Menurut Putra, Chabachib, Haryanto, dan Irine (2007) price to book value (PBV) menjadi sangat penting ketika ingin membuat suatu keputusan investasi, karena hampir semua keputusan investasi di pasar modal didasarkan pada perkembangan nilai PBV. Dalam kegiatan pasar modal khususnya dalam rangka investasi, seorang investor perlu memiliki keputusan investasi yang tepat serta mengetahui informasi tentang saham yang akan dibeli. Oleh karena itu informasi tentang penilaian saham menjadi sangat penting untuk diketahui oleh para investor. Investor dapat mempertimbangkan rasio PBV untuk membedakan saham mana yang harganya wajar, terlalu tinggi (overvalued), atau terlalu rendah (undervalued). Maksud dari undervalued adalah saham yang terjadi di pasar lebih rendah dari harga wajarnya atau disebut juga sebagai nilai fundamental saham. Sedangkan overvalued adalah harga saham di pasar jauh lebih tinggi dari nilai fundamental saham tersebut. Strategi ini pada umumnya mengkaitkan rasio PBV3 dengan nilai intrinsik saham yang diperkirakan berdasarkan model penilaian saham. Jika rasio yang berlaku dari suatu saham ternyata tidak konsisten dengan model penilaian saham, maka hal tersebut menunjukkan kemungkinan terdapatnya ketidakwajaran harga saham dan membuka peluang bagi investor untuk menentukan strategi investasinya sehingga menghasilkan imbal hasil saham (stock return) yang relatif tinggi.
Perubahan nilai PBV perusahaan dapat terjadi karena ada faktor-faktor yang mempengaruhinya. Putra et al, (2007) mengatakan bahwa salah satu rasio yang dapat mempengaruhi PBV yaitu rasio Debt to Equity Ratio (DER), semakin tinggi DER, semakin besar prosentase modal asing atau hutang yang digunakan dalam kegiatan operasional perusahaan karena DER menunjukkan tingkat hutang perusahaan sehingga mencerminkan risiko perusahaan semakin tinggi yang akan mempengaruhi harga saham dan akan mempengaruhi perubahan nilai PBV. Faktor lain yang mempengaruhi perubahan nilai PBV menurut Laksana (2010) yaitu ROA. Retun on asset menunjukkan kemampuan perusahaan dalam menghasilkan laba dengan pemanfaatan total aset yang dimiliki perusahaan. Oleh karena itu, ROA yang semakin meningkat dapat menunjukkan kinerja perusahaan yang semakin baik serta membantu perusahaan untuk terus tumbuh dan berkembang. Hal tersebut akan meningkatkan harapan dan keuntungan pemilik, serta cenderung akan menaikkan nilai saham perusahaan. Kemudian selain DER dan ROA, perhitungan Earning per Share (EPS) juga sangat penting karena pada dasarnya EPS menunjukan laba yang berhak didapatkan oleh pemegang saham atas satu lembar saham yang dimilikinya dan jika EPS meningkat maka kesejahteraan para pemegang saham akan meningkat dan semakin bertambahnya jumlah para pemegang saham di perusahaan tersebut akan menarik kepercayaan investor dan menaikan harga saham sehingga akan berdampak positif pada PBV perusahaan. Hal tersebut seperti hasil penelitian yang telah di lakukan oleh Putra et al, 2007.

Berbagai riset telah dilakukan untuk mengetahui pengaruh faktor-faktor fundamental yang dapat mempengaruhi PBV. Beberapa penelitian memiliki hasil yang sama namun ada juga yang berbeda seperti penelitian yang di lakukan oleh Pakpahan (2010) menyimpulkan bahwa 
DER, DPR, dan Growth secara parsial tidak berpengaruh signifikan terhadap nilai perusahaan yang di proksi dengan PBV. Sedangkan size dan ROE berpengaruh signifikan terhadap nilai perusahaan. Hal yang sama di katakan oleh Hidayati (2010) dalam penelitiannya yang menyimpulkan bahwa ROE dan size berpengaruh positif dan signifikan terhadap PBV. Sedangkan DER dan DPR berpengaruh negatif dan tidak signifikan ,terhadap PBV. Namun penelitian yang dilakukan Putra. et al, (2007) menyimpulkan bahwa ROA, beta saham, dan DPR tidak berpengaruh signifikan terhadap PBV.

\section{Rumusan Masalah}

1. Apakah Debt to Equity Ratio (DER) berpengaruh signifikan terhadap Price to Book Value (PBV)?

2. Apakah Return On Asset (ROA) berpengaruh signifikan terhadap Price to Book Value (PBV) ?

3. Apakah Earning Per Share (EPS) berpengaruh signifikan terhadap Price to Book Value (PBV)?

4. Apakah Debt to Equity Ratio (DER), Return On Asset (ROA), dan Earning Per Share (EPS) berpengaruh signifikan terhadap Price to Book Value (PBV) secara simultan ?

\section{REVIEW LITERATUR DAN HIPOTESIS}

\section{Landasan Teori}

\section{Laporan Keuangan}

Menurut Kasmir (2013), dalam praktiknya laporan keuangan oleh perusahaan tidak dibuat secara serampangan, tetapi harus dibuat dan disusun sesuai dengan aturan atau standar yang berlaku. Hal ini perlu dilakukan agar laporan keuangan mudah dibaca dan dimengerti. Laporan keuangan yang disajikan perusahaan sangat penting bagi manajemen dan pemilik perusahaan. Disamping itu, banyak pihak yang memerlukan dan berkepentingan terhadap laporan keuangan yang dibuat perusahaan, seperti pemerintah, kreditor, investor, maupun para pemasok.

Penggunaan laporan keuangan dalam analisis perusahaan dapat memberikan informasi bagi investor tentang kondisi perusahaan, termasuk pertumbuhan dan prospek perusahaan dimasa datang. Informasi seperti ini di perlukan investor dalam memprediksi pertumbuhan perusahaan dimasa datang, dan diperlukan dalam membuat keputusan investasi yang tepat. Hasil analisis laporan keuangan akan membantu investor dalam menentukan layak atau tidaknya suatu saham yang diterbitkan untuk dijadikan alternatif investasi. (Tandelilin, 2010).

\section{Price to Book Value (PBV)}

Brigham dan Houston (2006:111) menyatakan bahwa rasio atas harga pasar saham terhadap nilai bukunya juga akan memberikan indikasi yang lain tentang bagaimana investor memandang perusahaan. Perusahaan dengan tingkat pengembalian ekuitas yang relatif tinggi biasanya menjual dengan perkalian nilai buku yang lebih besar jika dibandingkan dengan perusahaan yang pengembaliannya rendah.

Menurut (Harahap, 2007:311) rasio ini menunjukan perbandingan harga saham di pasar dengan nilai buku tersebut. Rumus untuk mencari PBV sebagai berikut:

Market to Book Value $=\frac{\text { Nilai Pasar Saham }}{\text { Nilai Buku }}$

\section{Debt to Equity Ratio (DER)}

Menurut Kasmir (2013) Debt to Equity Ratio merupakan rasio yang digunakan untuk menilai utang dengan ekuitas. Rasio ini dicari dengan cara membandingkan antara seluruh utang, termasuk utang lancar dengan seluruh ekuitas. Rasio ini berguna untuk mengetahui jumlah dana yang disediakan peminjam (kreditur) dengan pemilik perusahaan. Dengan kata lain, rasio ini berfungsi untuk mengetahui setiap rupiah 
modal sendiri yang dijadikan untuk jaminan utang.

Bagi bank (kreditur), semakin besar rasio ini, akan semakin tidak menguntungkan karena akan semakin besar risiko yang ditanggung atas kegagalan yang mungkin terjadi di perusahaan. Namun bagi perusahan justru semakin besar rasio akan semakin baik. Sebaliknya dengan rasio yang rendah, semakin tinggi tingkat pendanaan yang di sediakan pemilik dan semakin besar batas pengamanan bagi peminjam jika terjadi kerugian atau penyusutan terhadap nilai aktiva. Rasio ini juga memberikan petunjuk umum tentang kelayakan dan risiko keuangan perusahaan.

Menurut Prastowo (2010) dalam rangka mengukur risiko, fokus perhatian kreditor jangka panjang terutama ditujukan pada prospek laba dan perkiraan arus kas. Meskipun demikian, mereka tidak dapat mengabaikan pentingnya tetap mempertahankan keseimbangan antara proporsi aktiva yang ditandai oleh kreditor dan yang ditandai oleh pemilik perusahaan.

Keseimbangan proporsi antara aktiva yang ditandai oleh kreditor dan yang didanai oleh pemilik perusahaan diukur dengan ratio debt to equity, dengan cara perhitungan sebagai berikut:

\section{Debt to Equity $=\frac{\text { Totalutang }}{\text { total ekuitas }}$}

\section{Return On Asset (ROA)}

Menurut Prastowo (2011) return on asset mengukur kemampuan perusahaan dalam memanfaatkan aktivanya untuk memperoleh laba. Ratio ini mengukur tingkat kembalian investasi yang telah dilakukan oleh perusahaan dengan menggunakan seluruh dana (aktiva) yang dimilikinya. Ratio ini dapat di perbandingkan dengan tingkat bunga bank yang berlaku.

Return On Asset $=\frac{\text { labasetela } h \text { pajak tetapisebelumbunga }}{\text { aktiva rata }- \text { rata }}$
Laba yang dipakai disini adalah laba sebelum bunga, setelah pajak, untuk menggambarkan besarnya laba yang diperoleh perusahaan sebelum didistribusikan baik kepada kreditur maupun pemilik perusahaan. Menurut Putra et al, (2007) ROA pada dasarnya merupakan kemampuan perusahaan untuk dapat menghasilkan keuntungan dengan pemanfaatan aktiva yang dimiliki perusahaan

\section{Earning Per Share}

Menurut Tandelilin

(2010)

komponen penting pertama yang harus di perhatikan dalam analisis perusahaan adalah laba per lembar saham atau lebih di kenal sebagai Earning per Share (EPS). Informasi EPS suatu perusahaan menunjukkan besarnya laba bersih perusahaan yang siap di bagikan bagi semua pemegang saham perusahaan. Besarnya EPS suatu perusahaan dapat diketahui dari informasi laporan keuangan perusahaan. Meskipun beberapa perusahaan tidak mencantumkan besarnya EPS perusahaan bersangkutan dalam laporan keuangannya, tetapi besarnya EPS suatu perusahaan dapat di hitung berdasarkan infornasi laporan neraca dan laporan rugi laba perusahaan.

Rumus untuk menghitung EPS suatu perusahaan adalah sebagai berikut:

$$
\mathrm{EPS}=\frac{\text { Laba bersi } h \text { setela } h \text { bunga dan pajak }}{\text { jumla } h \text { saham beredar }}
$$

\section{Penelitian Terdahulu}

Beberapa penelitian terdahulu tentang pengaruh DER, ROA, dan EPS terhadap PBV diantaranya:

1. Hasil penelitian Budi dan Eka Nuraini Rachmawati (2014) menunjukkan bahwa secara simultan ROE, DER, Growth, dan firm size berpengaruh positif dan signifikan terhadap PBV secara simultan. Sedangkan ROE, DER, dan growth berpengaruh positif dan signifikan terhadap $\mathrm{PBV}$, firm size 
berpengaruh positif dan tidak signifikan terhadap PBV.

2. Hasil penelitian Putra et al, (2007) menunjukkan bahwa secara simultan (bersama-sama) terdapat pengaruh antara ROA, DER, EPS, Beta Saham dan DPR terhadap PBV. Sedangkan secara parsial (masing-masing menunjukkan bahwa EPS dan DER berpengaruh positif dan signifikan terhadap PBV. sedangkan ROA, Beta Saham, dan DPR tidak berpengaruh signifikan terhadap PBV.

3. Hasil penelitian Nurhayati (2013) menunjukkan bahwa ukuran perusahaan dan likuiditas berpengaruh negatif dan signifikan terhadap kebijakan dividen, sedangkan pada nilai perusahaan, ukuran perusahaan berpengaruh positif dan signifikan. Profitabilitas berpengaruh positif dan signifikan terhadap kebijakan dividen dan nilai perusahaan.

\section{Hipotesis}

H1: Debt to Equity Ratio (DER) berpengaruh signifikan terhadap Price to Book Value (PBV).

H2: Return On Asset (ROA) berpengaruh signifikan terhadap Price to Book Value (PBV)

H3: Earning Per Share (EPS) berpengaruh signifikan terhadap Price to Book Value (PBV)

H4: DER, ROA, dan EPS berpengaruh signifikan terhadap PBV secara simultan.

\footnotetext{
METODE PENELITIAN

Populasi dan Sampel

Menurut Sugiyono (2012) populasi adalah wilayah generalisasi yang terdiri atas: objek atau subjek yang mempunyai kualitas dan karakteristik tertentu yang ditetapkan oleh peneliti untuk dipelajari dan kemudian ditarik kesimpulannya. Populasi dalam penelitian ini adalah seluruh perusahaan Telekomunikasi yang terdaftar di BEI.
}

Sugiyono (2012) menyatakan bahwa sampel adalah bagian dari jumlah dan karakteristik yang dimiliki oleh populasi tersebut. Teknik pengambilan sampel dalam penelitian ini menggunakan sampling jenuh, menurut Sugiyono (2012) sampling jenuh adalah teknik penentuan sampel bila semua anggota populasi digunakan sebagai sampel.

\section{Definisi Operasional}

1. Variabel Dependen

\section{Debt to Equity Ratio (DER)}

Menurut Putra, et al. (2007) DER merupakan rasio solvabilitas yang digunakan untuk mengukur tingkat leverage (penggunaan hutang) terhadap total shareholder's equity yang dimiliki perusahaan. Seacara sistematis DER dapat dirumuskan sebagi berikut:

DER $=\frac{\text { TotalHutang }}{\text { TotalEkuitas }}$

\section{Return On Asset (ROA)}

Dwipratama (2009) Rasio ini mencerminkan kemampuan perusahaan dalam memperoleh laba bersih setelah pajak dari total aset yang digunakan untuk operasional perusahaan. Rumus untuk mencari ROA adalah sebagai berikut:

$$
\text { ROA }=\frac{\text { NetIncomeAfterTax }}{\text { TotalAsset }}
$$

\section{Earning Per Share (EPS)}

Menurut Defrizal (2005) EPS merupakan perbandingan antara pendapatan yang dihasilkan (laba Bersih) setelah pajak kemudian di bandingkan dengan jumlah saham beredar. EPS dapat dirumuskan sebagai berikut:

\section{Alat Statistik}

a. Uji Normalitas

Uji normalitas digunakan untuk mengetahui apakah populasi data berdistribusi normal atau tidak. Uji ini biasanya digunakan untuk mengukur data berskala ordinal, interval, ataupun 
rasio. Dasar pengambilan keputusan uji normalitas sebagai berikut:

1. Data berdistribusi normal, jika nilai sig (signifikansi) $>0,05$.

2. Data berdistribusi tidak normal, jika nilai sig (signifikansi) $<0,05$

b. Uji Multikolinearitas

Tujuan dari uji multikolinearitas adalah untuk menguji apakah pada sebuah model regresi ditemukan adanya korelasi antar variabel independen. Jika terjadi korelasi, maka dinamakan problem multikolinearitas (multikol). Untuk mendeteksi ada atau tidaknya gejala multikolinieritas adalah sebagai berikut: Melihat nilai tolerance:

1. Tidak terjadi multikolinearitas jika nilai tolerance lebih besar dari 0,10

2. Terjadi multikolinearitas jika nilai tolerance lebih kecil atau sama dengan 0,10

Melihat nilai VIF (Variance Inflation Factor)

1. Tidak terjadi multikolinearitas jika nilai VIF 10,0020

2. Terjadi multikolinearitas jika nilai VIF lebih besar atau sama dengan 10,00

c. Uji Heteroskesdastisitas

Uji Heteroskedastisitas bertujuan untuk menguji apakah dalam model regresi terjadi ketidaksamaan variance dari residual satu pengamatan ke pengamatan yang lain. Model regresi yang baik maka tidak terjadi heteroskedastisitas. Dengan dasar Pengambilan Keputusan sebagai berikut:

1. Tidak terjadi heteroskedastisitas, jika nilai t-hitung $<\mathrm{t}$-tabel dan nilai signifikansi $>$ dari 0,05 .

2. Terjadi heteroskedastisitas, jika nilai t-hitung > dari t-tabel dan nilai signifikansi $<$ dari 0,05 .

d. Uji Autokorelasi

Uji autokorelasi digunakan untuk mengetahui ada atau tidaknya penyimpangan asumsi klasik autokorelasi yaitu korelasi yang terjadi antara residual pada satu pengamatan dengan pengamatan lain pada model regresi. Prasyarat yang harus terpenuhi adalah tidak adanya autokorelasi dalam model regresi. Metode pengujian yang digunakan dalam penelitian ini adalah dengan uji Breusch Godfrey, Uji B-G sering juga disebut sebagai uji LM21 (Lagrange Multiplier). Uji ini dapat menutupi kelemahan pada uji DW ketika memberikan hasil "tidak ada kesimpulan" pengambilan keputusan dapat dilakukkan sebagai berikut:

1. Prob Chi Square >0,05 yang berarti tidak terjadi autokorelasi

2. Prob Chi Square < 0,05 yang berarti terjadi autokorelasi.

\section{Teknik Analisis Data}

1. Analisis Regresi Berganda

Regresi Linier Berganda

Pengujian hipotesis menggunakan

persamaan Regresi linier Berganda dengan rumus sebagai berikut:

$\mathrm{Y}=\alpha+\beta 1 \mathrm{X} 1+\beta 2 \mathrm{X} 2+\beta 3 \mathrm{X} 3+\mathrm{e}$

Keterangan:

$\mathrm{Y}=\mathrm{PBV}$

$\alpha=$ Konstanta

$\beta 1,2,3=$ Koefisien Regresi

$\mathrm{X} 1=\mathrm{DER}$

$\mathrm{X} 2=\mathrm{ROA}$

$\mathrm{X} 3=\mathrm{EPS}$

$\mathrm{e}=$ Eror $/$ residual

\section{Uji Hipotesis}

1. Uji Parsial (Uji T)

Uji signifikansi individual (uji t) digunakan untuk menguji masingmasing variabel independen terhadap variabel dependen dengan tingkat $\alpha=5 \%$.

a. Jika sig<0,05 maka Ha diterima, berarti variabel independen secara parsial berpengaruh terhadap variabel dependen.

b. Jika sig>0,05 maka Ha ditolak, berarti variabel independen secara 
parsial tidak berpengaruh terhadap variabel dependen.

\section{Uji Simultan (Uji F)}

Uji signifikansi simultan (uji f) digunakan untuk melihat pengaruh seluruh variabel independen terhadap variabel dependen dengan tingkat $\alpha=$ $5 \%$.

a. Jika sig F-hitung <0,05 maka Ha diterima, berarti variabel independen secara simultan berpengaruh terhadap variabel dependen.

b. Jika sig F-hitung >0,05 maka Ha ditolak, berarti variabel independen secara simultan tidak berpengaruh terhadap variabel dependen.

\section{Uji Koefisien Determinasi}

Koefisien deteminasi digunakan untuk menguji besarnya presentase variasi variabel dependen yang dapat dijelaskan oleh variasi variabel independen. Nilai determinasi adalah antara nol sampai satu. Nilai Ajusted R2 yang kecil berarti kemampuan variabel-variabel independen dalam menjelaskan variasi variasi variabelvariabel dependen memberikan hampir semua informasi yang dibutuhkan untuk memprediksi variasi variabel dependen.

\section{HASIL PENELITIAN DAN PEMBAHASAN}

\section{Statistik Deskriptif \\ Statistik Deskriptif}

\begin{tabular}{|c|c|c|c|c|c|}
\hline & $\mathrm{N}$ & minimum & maximum & Mean & Std. Deviation \\
\hline DER & 30 & -38.53 & 79.69 & 2.8397 & 16.29436 \\
\hline ROA & 30 & -0.34 & 0.16 & 0.0077 & 0.13395 \\
\hline EPS & 30 & -678.97 & 637.40 & 98.6297 & 304.98395 \\
\hline PBV & 30 & -17.94 & 13.03 & 2.3603 & 4.88511 \\
\hline \multicolumn{5}{|c}{ Sumber: Data diolah Juni 2015 }
\end{tabular}

Variabel DER (Debt to Equity Ratio) mempunyai nilai minimum sebesar $-38,53$ terdapat pada perusahaan FREN, nilai maximum sebesar 79,65 terdapat 25 pada perusahaan BTEL dan nilai rata-rata (mean) sebesar 2,8397 dengan nilai standar deviasi sebesar 16, 29436.
Variabel ROA (Return On Asset) mempunyai nilai minimum sebesar - 0,34 terdapat pada perusahaan BTEL dan nilai maximum sebesar 0,16 terdapat pada perusahaan TLKM dan nilai rata-rata sebesar 0,0077 dengan nilai standar deviasi sebesar 0,13395.

Variabel EPS (Earning Per Share) mempunyai nilai minimum sebesar 678,97 terdapat pada perusahaan BTEL dan nilai maximum sebesar 637,40 terdapat pada perusahaan TLKM dan nilai rata-rata sebesar 98,6297 dengan nilai standar deviasi sebesar 304,98395.

Variabel PBV (Price to Book Value) mempunyai nilai minimum sebesar $-17,94$ terdapat pada perusahaan FREN dan nilai maximum sebesar 13,03 terdapat pada perusahaan BTEL dan nilai rata-rata sebesar 2,3603 dengan nilai standar deviasi sebesar 4,88511.

\section{Uji Asumsi Klasik} Uji Normalitas

Tabel 4.2
Uji Normalitas
\begin{tabular}{|c|c|c|}
\hline \multicolumn{3}{c}{} \\
\hline & p-value (sign) & Keterangan \\
\hline One Sampel KS & 0,559 & Data Berdistribusi Normal \\
\hline
\end{tabular} Sumber: Data diolah Juni 2015

Tabel diatas menunjukan nilai $\mathrm{p}$-value (sign) yang diperoleh adalah sebesar $0,559>0,05$ yang berarti data berdistribusi normal.

\section{Uji Autokorelasi}

Tabel 4.5

Uji Autokorelasi

\begin{tabular}{l|l|l|c|}
\hline \multicolumn{4}{|c|}{ Breusch-Godfrey serial correlation LM test: } \\
\hline F-statistic & 0,761 & Prob. F(2,24) & 0,9351 \\
\hline Obs*R-squared & 0,789 & Prob. Chi-square(2) & 0,9197 \\
\hline Sumber: Data diolah Juni 2015
\end{tabular}

Tabel diatas menunjukkan bahwa nilai prob. Chi-square sebesar $0,9197>0,05$ yang berarti tidak terjadi autokorelasi.

\section{Uji Heteroskedastisitas}

Tabel 4.4

Uji Heteroskesdatisitas

\begin{tabular}{|c|c|c|c|}
\hline Variabel terikat & Variabel bebas & sig & Keterangan \\
\hline RES2 & DER & 0,561 & Non heteroskesdastisitas \\
\hline & ROA & 0,314 & Non heteroskesdastisitas \\
\hline & EPS & 0,512 & Non heteroskesdastisitas \\
\hline
\end{tabular}


Tabel 4.4 menunjukkan tidak ada satupun variabel bebas yang signifikan secara statististik mempengaruhi variabel terikat RES2. Hal ini dapat dilihat dari probabilitas signifikanya $>$ 0,05. Jadi dapat disimpulkan model regresi ini tidak menunjukkan adanya heteroskesdastisitas.

\section{Uji Multikolineiritas}

\begin{tabular}{|c|c|c|c|}
\hline \multirow[b]{3}{*}{ Variabel bebas } & \multicolumn{3}{|c|}{$\begin{array}{c}\text { Tabel } 4.3 \\
\text { Uji Mulikolinearitas }\end{array}$} \\
\hline & \multicolumn{2}{|c|}{ Collinearity Statistic } & \multirow[b]{2}{*}{ Kesimpilan } \\
\hline & Tolerance & VIF & \\
\hline DER & 0,990 & 1,010 & \begin{tabular}{|l} 
Tidak terjadi multikolinearitas \\
\end{tabular} \\
\hline ROA & 0,833 & 1,201 & Tidak terjadi multikolinearitas \\
\hline EPS & 0,827 & 1,208 & Tidak terjadi multikolinearitas \\
\hline
\end{tabular}

Hasil olah data pada tabel diatas menunjukkan bahwa masing-masing vaeiabel bebas memiliki nilai tolerance > 0,10 . Nilai variance inflation factor (VIF) untuk masing-masing variabel $<10$. Hal ini menunjukkan bahwa variabel DER, ROA, dan EPS tidak mengandung multikolinearitas.

\section{Hasil Uji Regresi Linier Berganda}

Tabel 4.6

\begin{tabular}{|c|c|c|c|}
\hline \multicolumn{4}{|c|}{ Hasil Perhitungan Regresi } \\
\hline Variabel & Koef.B & $t$-value & Sign.t \\
\hline konstanta & 1.792 & 3.484 & 0.002 \\
\hline DER & 0.214 & 7.144 & 0.000 \\
\hline ROA & 19.987 & 5.026 & 0.000 \\
\hline EPS & -0.002 & -1.120 & 0.273 \\
\hline Sign F & 0.000 & & \\
\hline Adj. $R^{2}$ & 0.713 & & \\
\hline
\end{tabular}

Tabel 4.7

Ringkasan Hasil Pengujian Hipotesis

\begin{tabular}{|c|c|}
\hline Hipotesis & Keterangan \\
\hline 1. DER berpengaruh signifikan terhadap PBV & Ha diterima \\
\hline 2. ROA berpengaruh signifikan terhadap PBV & Ha diterima \\
\hline 3. EPS berpengaruh tidak signifikan terhadap PBV & Ha ditolak \\
\hline $\begin{array}{l}\text { 4. DER, ROA, dan EPS secara simultan } \\
\text { berpengaruh signifikan terhadap PBV }\end{array}$ & Ha diterima \\
\hline
\end{tabular}

Berdasarkan hasil perhitungan regresi pada tabel 4.6 diperoleh persamaan regresi sebagai berikut:

$\mathrm{PBV}=1,792+0,214 \mathrm{DER}+19,987 \mathrm{ROA}$ $+-0,002 \mathrm{EPS}+\mathrm{e}$

\section{Uji Signifikansi Nilai $t$}

a. Uji Hipotesis 1

Variabel DER (Debt to Equity Ratio) memiliki koefiien regresi positif sebesar 0,214 dengan nilai sign $(0,00)<\alpha$
$(0,05)$, berarti DER berpengaruh positif dan signifikan terhadap PBV. Peningkatan 1 satuan pada DER akan meningkatkan PBV sebesar 0,214 satuan. Hipotesis $1 \quad$ (H1) terbukti/diterima.

b. Uji Hipotesis 2

Variabel ROA memiliki koefiien regresi positif sebesar 19,987 dengan nilai sign $(0,00)<\alpha(0,05)$, berarti DER berpengaruh positif dan signifikan terhadap PBV. Peningkatan 1 satuan pada DER akan meningkatkan PBV sebesar 19,987 satuan. Hipotesis 2 (H2) terbukti/diterima.

c. Uji Hipotesis 3

Variabel EPS (Earning Per Share) memiliki koefiien regresi negatif sebesar $-0,002$ dengan nilai sign $(0,00)$ $<\alpha(0,05)$, berarti DER berpengaruh negatif dan tidak signifikan terhadap PBV. Peningkatan 1 satuan pada DER akan m PBV sebesar -0,002 satuan. Hipotesis 3 (H3) terbukti/diterima.

2. Hasil Uji Simultan (Uji F)

Tabel 4.6 menunjukkan hasil uji nilai $\mathrm{F}$ diperoleh $\mathrm{p}$-value $(0,000)<\alpha$ $(0,05)$, berarti DER (Debt to Equity Ratio), ROA (Return On Asset), dan EPS (Earning Per Share) secara serempak berpengaruh signifikan terhadap PBV (Price to Book Value).

3. Hasil Uji Koefisien Determinasi

Nilai Ajusted Rsquare sebesar 0,713 menunjukkan bahwa $71,3 \%$ variasi PBV (Price to Book Value) dapat di jelaskan oleh variabel DER (Debt to Equity Ratio), ROA (Return On Asset), dan EPS (Earning Per Share). Sedang sisanya $29,7 \%$ dijelaskan variabel lain diluar model penelitian.

\section{Pembahasan}

Hasil pengujian hipotesis pertama dapat di simpulkan bahwa DER berpengaruh positif dan signifikan terhadap PBV. Hasil penelitian ini sejalan 
dengan hasil penelitian yang dilakukan oleh Putra et al, (2007), Budi dan Rachmawati (2014) yang menyatakan bahwa DER berpengaruh positif dan signifikan terhadap PBV. yang berarti jika DER meningkat, maka nilai PBV juga akan meningkat. Artinya bahwa kebijakan hutang bukan dinilai sebagai sesuatu yang terlalu mengkhawatirkan perusahaan. Dalam hal ini kebijakan menambah hutang dipandang sebagai sebuah sinyal pertumbuhan perusahaan. Perusahaan yang sedang dalam pertumbuhan akan membutuhkan pendanaan yang besar. Hal ini tidak mungkin dapat dipenuhi hanya dari modal sendiri, sehingga perusahaan memutuskan untuk membentuk hutang baru pada pihak ketiga atau kreditor selama tambahan hasil investasi lebih besar daripada tambahan biaya hutang.

Hasil pengujian kedua dapat disimpulkan bahwa ROA berpengaruh positif dan signifikan terhadap PBV. Hasil penelitian ini sejalan dengan penelitian yang dilakukan oleh Nurhayati (2013) yang menyatakan bahwa ROA berpengaruh positif dan signifikan terhadap nilai perusahaan. Artinya profit yang semakin tinggi akan memberikan indikasi prospek perusahaan yang baik sehingga dapat memicu investor untuk ikut meningkatkan permintaan saham. Meningkatnya permintaan saham akan menyebabkan nilai perusahaan juga meningkat.

Hasil pengujian ketiga dapat disimpulkan bahwa EPS berpengaruh negatif dan tidak signifikan terhadap PBV. Hal ini mengindikasikan bahwa EPS yang menurun akan mencerminkan hasil investasi perlembar saham juga akan menurun, sehingga harga saham juga akan ikut menurun dan dampak akhirnya pada PBV akan ikut menurun.

\section{KESIMPULAN DAN SARAN}

\section{Kesimpulan}

1. Variabel DER berpengaruh positif dan signifikan terhadap variabel PBV. yang berarti jika DER meningkat, maka nilai PBV juga akan meningkat.

2. Variabel ROA berpengaruh positif dan signifikan terhadap PBV. Hal ini menunjukkan bahwa semakin efisien perputaran asset dan atau semakin tinggi profit margin yang diperoleh perusahaan maka akan semakin baik nilai perusahaan.

3. Variabel EPS berpengaruh negative dan tidak signifikan terhadap PBV. hal ini menunjukkan bahwa EPS yang negatif akan menurunkan nilai PBV.

4. DER (Debt to Equity Ratio), ROA (Return On asset), dan EPS (Earning Per Share) berpengaruh signifikan terhadap PBV (Price to Book Value) secara simultan.

\section{Saran}

1. Bagi perusahaan yang ingin meningkatkan nilai perusahaannya dengan menggunakan tolok ukur rasio price to book value (PBV), maka disarankan untuk lebih memperhatikan faktor yang mempengaruhi rasio PBV tersebut, yaitu DER (Debt to Equity Ratio) dan ROA (Return On Asset) karena keduanya merupakan faktor yang secara parsial memiliki pengaruh signifikan terhadap rasio PBV dalam penelitian ini.

2. Bagi investor yang ingin menanamkan modalnya (berinvestasi) pada sebuah perusahaan, sebaiknya lebih memperhatikan rasio PBV dalam membuat keputusan investasi.

3. Bagi peneliti selanjutnya disarankan untuk memperpanjang periode penelitian serta memperluas sampel perusahaan dengan mencakup industriindustri pasar modal lainnya seperti industri keuangan dan manufaktur. Peneliti selanjutnya juga disarankan 
untuk menambah variabel independen lainnya sehingga dapat diperoleh gambaran yang lebih jelas mengenai faktor-faktor yang mempengaruhi rasio PBV.

\section{DAFTAR PUSTAKA}

Andriani, Megawati dan Irawati Juanaeni. (2011). Pengaruh DER, ROA, dan EPS Terhadap PBV Pada Perbankan yang Terdaftar di BEI periode 20062010. Business \& Management Review, vol. 2 no. 1, 203-215.

Brigham, Eugene dan Joel F. Houston. 2006. Dasar-dasar Manajemen Keuangan. Edisi kesepuluh. Jakarta: Salemba Empat.

Budi, Eka Sapram dan Eka Nuraini Rachmawati. (2014). Analisis Pengaruh Return On Equity, Debt to Equity Ratio, Growth, dan Firm Size Terhadap Price to Book Value Pada Perusahaan Property dan Real Estate di Bursa Efek Indonesia. Jurnal Ekonomi, Manajemen dan Akutansi, Vol. 22, No. 1, Juni 2014

Defrizal, Herry. (2005). Analisis Pengaruh Faktor-faktor Fundamental Terhadap Harga Saham dan Perbandingan Harga Saham dengan Nilai Normatif. Tesis Manajemen. Universitas Diponegoro.

Dwipratama, Gede Priana. (2009). Pengaruh PBV, DER, EPS, DPR, dan ROA Terhadap Harga Saham: Study Empiris pada Perusahaan Food and Beverage yang Terdaftar di BEI. Skripsi Akuntansi. Universitas Gunadarma.

Haikal, Salahudin. 2004. Key Management Ratios. Edisi ketiga. Jakarta: Salemba Empat.
Harahap, Sofyan Syafri. 2007. Analisis Kritis Atas Laporan Keuangan. Jakarta: PT. Rajagrafindo Persada.

Hidayati, Eva Eko. (2010). Analisis Pengaruh DER, DPR, dan Size Terhadap PBV Perusahaan Manufaktur yang Listing di BEI Periode 2005-2007. Semarang: Tesis Manajemen. Universitas Diponegoro.

Kasmir. 2013. Analisis Laporan Keuangan. Jakarta Utara : PT. Rajagrafindo Persada.

Laksana, Banter. (2010). Dampak LDR dan ROA Terhadap Nilai Perusahaan: Study kasus pada Perusahaan Jasa Perbankan yang Terdaftar di Bursa Efek Indonesia periode 2001-2007. Jurnal Ekonomi, Keuangan, Perbankan, dan Akuntansi. Vol 2. No 1 Mei 2010, hal 35-46.

Nurhayati, Mafizatun. (2013). Pengaruh Profitabilitas, Likuiditas, dan Ukuran Perusahaan Terhadap Kebijakan Dividend an Nilai Perusahaan. Jurnal Keuangan dan Bisnis. Vol. 5, No. 2, Juli 2013.

Nasehah, Widyarti, (2012). Analisis Pengaruh ROE, DER, DPR, Growth, dan Firm Size terhadap PBV study kasus pada perusahaan manufakatur yang listed diBEI periode 20072010. Diponegoro Journal Management. Vol. 1, No. 1, Tahun 2012, hal 1-9.

Pakpahan, Rosma, (2010). Pengaruh Faktor-Faktor Fundamental Perusahaan dan kebijakan Diviiden Terhadap Nilai Perusahaan. Jurnal Ekonomi Keuangan. Vol.2 No.2 Tahun 2010 
Prastowo, Andi. 2010. Memahami Metode-metode Penelitian. Yogyakarta: Arus Media.

Prastowo, dwi. 2011. Analisis Laporan Keuangan: Konsep dan Aplikasi. Edisi Ketiga. Yogyakarta: Unit Penerbit dan Percetakan Sekolah Tinggi Ilmu Ekonomi YKPN.

Prastowo, Dwi dan Rifka Juliaty. 2008. Analisis Laporan Keuangan : Konsep dan Aplikasi. Yogyakarta: Sekolah Tinggi Ilmu Manajemen YKPN.

Putra, Tito Perdana, M. Chabachib, Mulyo Haryanto, dan Irine Rini Demi Pangestuti. (2007). Pengaruh Kinerja Keuangan dan Beta Saham Terhadap Price to Book Value: Study pada Perusahaan Real Estate dan Property yang Listed di Bursa Efek Indonesia Periode Tahun 2004-2006. Jurnal Study Manajemen dan Organisasi. Vol 4. No.2, hal 1-15.

Sugiyono. 2012. Metode Penelitian Bisnis. Bandung : Penerbit Alfabeta.

Tandelilin, Eduardus. 2010. Portofolio dan Investasi: Teori dan Aplikasi. Edisi Pertama. Yogyakarta: Kanisius. 